\title{
The Use of Humanoid Robots with Multilingual Interaction Skills in Teaching a Foreign Language: Opportunities, Research Challenges and Future Research Directions
}

Ayse TunA $^{1}$ ANd Gurkan TunA ${ }^{\star 2}$

$\approx$ Since a humanoid robot does not get tired regardless of how many mistakes a student makes, and because it can be equipped with novel teaching techniques and updated with the most current knowledge, it can be useful for achieving many educational goals. The rationale behind this is that it has been shown in the literature that robots are more useful as teaching aids than computers or other instructional tools, as they can mimic human responses. Furthermore, humans, especially children, prefer robot interaction to other interaction types. Adults generally struggle to learn a foreign language, but this is true of some students, too. With their multilingual interaction capabilities, their ability to provide real-time feedback, and their humanlike physical shape, some types of humanoid robots can be of great assistance to students in learning a foreign language. The use of humanoid robots leads to a personal connection with the students, and this can help overcome issues related to shyness, reluctance, frustration and lack of confidence that may emerge in dealing with a human teacher. Moreover, as humanoid robots can be programmed to know specifically what each individual student needs to learn, they can be quite useful for one-on-one speaking activities. Considering the many possibilities that can be offered by information and communication technology tools, particularly by humanoid robots, this paper reviews the roles and functions of humanoid robots in teaching a foreign language, presents novel approaches in this domain, provides research challenges, and finally outlines future research directions.

Keywords: humanoid robots, real-time feedback, repeatability, multilingual interaction skills, foreign language teaching

1 School of Foreign Languages, Trakya University, Edirne, Turkey.

2 *Corresponding Author. Department of Computer Programming, Trakya University, Edirne, Turkey; gurkantuna@trakya.edu.tr. 


\section{Uporaba humanoidnih robotov $\mathrm{z}$ večjezičnimi} interakcijskimi veščinami pri poučevanju tujega jezika: priložnosti, raziskovalni izzivi in prihodnje raziskovalne usmeritve

Ayse Tuna in Gurkan Tuna

$\approx$ Ker se humanoidni robot ne utrudi ne glede na to, koliko napak učenec naredi, in ker je opremljen $\mathrm{z}$ novimi učnimi tehnikami ter posodobljen z najnovejšim znanjem, je lahko koristen za doseganje številnih izobraževalnih ciljev. Razlogi za to izhajajo iz literature, ki dokazuje, da so roboti kot učni pripomoček uporabnejši kot računalniki in druga izobraževalna orodja, saj lahko posnemajo človeške odzive. Še več, ljudje, posebej otroci, imajo interakcije z roboti raje od drugih oblik interakcije. Odrasli se na splošno težje naučijo tujega jezika, vendar pa to velja tudi za nekatere učence. Nekatere vrste humanoidnih robotov so lahko s svojimi večjezičnimi interakcijskimi sposobnostmi, z zmožnostjo podajanja povratne informacije v realnem času ter s svojim, človeku podobnim videzom v veliko pomoč učencem pri učenju tujega jezika. Uporaba humanoidnih robotov vodi v osebno povezanost $\mathrm{z}$ učencem, kar lahko pomaga pri premagovanju težav, povezanih s sramežljivostjo, $\mathrm{z}$ odporom, s frustracijo in pomankanjem samozavesti, ki se lahko pojavijo pri učenju s človeškim učiteljem. Poleg tega so lahko koristni pri govornih aktivnostih »ena-na-ena«, saj so humanoidni roboti lahko sprogramirani tako, da točno vedo, kaj se mora določen učenec naučiti. Upoštevaje številne možnosti, ki jih lahko ponudijo orodja informacijsko-komunikacijske tehnologije, še zlasti humanoidni roboti, ta prispevek preučuje vloge in funkcije humanoidnih robotov pri poučevanju tujega jezika, predstavlja nove pristope na tem področju in raziskovalne izzive, na koncu pa nakazuje prihodnje raziskovalne usmeritve.

Ključne besede: humanoidni roboti, realnočasovna povratna informacija, ponovljivost, večjezične interakcijske veščine, poučevanje tujega jezika 


\section{Introduction}

Due to its benefits, the idea of personalised learning has gained popularity in recent years and the use of technology and computer-based solutions has moved to the centre of personalised learning. Personalised learning is a way of teaching centred on the interests and needs of each student instead of the class as a whole. It includes flexible learning environments and specially designed education plans. Currently, computer programmes supported by artificial intelligence and machine learning techniques are able to learn students' individual learning styles and tailor lessons to suit their precise needs. As a result, each student can work at his/her own pace and benefit from customised lesson plans personalised to suit his/her exact level in each lesson.

Although novel instructional tools can assist in foreign language learning in different ways (Yang \& Chen, 2007), they are difficult to customise and time-consuming and impractical to interact with (Chang et al., 2010). Moreover, if the learning content carried by them does not match the students' level, adopting these tools alone does not significantly improve learning (Hegarty, 2004). Unlike these tools, humanoid robots have body shapes that are built to resemble the human body and have social interaction skills. They can be designed for a range of purposes, including interaction with human tools and environments, the study of locomotion, and many others. Although humanoid robots are currently mainly used for a few specific repetitive tasks in foreign language teaching, many other possibilities exist. For instance, it has been shown that children treat humanoid robots as important players in the classroom setting; most children are willing to listen to the instructions they receive from humanoid robots and answer the humanoid robots' questions. The success of humanoid robots in the classroom setting lies in the fact that they do not punish children if they make a mistake (Kwok, 2015). If a teacher uses a humanoid robot in learning activities, the role of the teacher is directly linked to the role that the robot plays (Mubin et al., 2013). For instance, if the humanoid robot acts as the main focal entity in a learning activity, the teacher takes on the role of a facilitator (Alimisis, 2012). On the other hand, if the robot takes on a passive role, the teacher should transfer the base knowledge. The major problem with the humanoid robot acting as the main focal entity is that, in some situations in the classroom setting, humanoid robots may not be able to fully understand and interpret children's intentions due to inaccurate speech or emotion recognition, and this may result in a loss of interaction (Honig \& Oron-Gilad, 2018).

Some humanoid robots, such as NAO, can be programmed to have multilingual interaction skills ("Available languages - Aldebaran 2.1.4.13 documentation", 2019), so they can help build a positive and productive learning environment 
for students to practise real-life conversations in foreign language teaching programmes. These robots can also play a key role in enhancing cross-cultural communication, as long as they are able to behave and respond in a culturally appropriate manner. Although English is widely accepted for social interaction, integration in society in general and especially in the job market is very dependent on the native language of a country. Many societal agencies therefore arrange a language cafe, an open gathering at which native and non-native speakers spontaneously gather to engage in open-topic social conversations with the goal of maintaining the conversation in the target language, in order to help learners practise conversation to complement traditional classroom teaching (Lopes, Engwall, \& Skantze, 2017). In language cafes, although native speakers have the role of equal conversational partners, they are given the extra responsibility of initiating the conversations and assisting the target language learners. The present study focuses on the use of humanoid robots in foreign language teaching and presents novel approaches to their roles for this purpose. Moreover, research challenges are presented and future research directions are stated.

\section{The use of humanoid robots in education}

It is known that, compared to a robot, a computer offers fewer opportunities to interact, and that interacting with a robot activates social areas of the brain that are not activated when using a computer (Dautenhahn, 2007). Since humans have evolved to be a social species, we are naturally programmed to pay more attention to human-like robots, i.e., humanoid robots, than to computer screens (ibid.). The social stimuli and the greater response to interactions with humanoid robots therefore account for the possible success of robot teachers.

While robot teachers were initially used to teach science, technology, engineering and mathematics (STEM) in schools, they are now also programmed to teach languages or assist in language teaching (Belpaeme et al., 2018; Scassellati et al., 2018). Although it is impossible that humanoid robots will take over the work of human teachers in the next few years, human teachers and humanoid robots will work together to provide additional opportunities and personalised education to students.

The use of humanoid robots in education will consequently change the roles of teachers, who will be less focused on common repetitive tasks and will instead enhance their roles as leaders, overall organisers, explainers and final evaluators. This may prove to be an economically viable solution to the shortage of teachers, too. Moreover, humanoid robots can help teachers and students to solve several open-ended problems; for instance, humanoid robots can determine each 
student's individual preferences, motivations and difficulties, and can thus match the student's speed of learning and adapt to his/her needs. In the classroom, working with humanoid robots engages children and can bring high technology down to the practical everyday level. As listed in Table 1, four main roles can be identified for the use of a humanoid robot in education. The benefits of working with humanoid robots for educational goals are listed below (Chang et al., 2010; Jamet et al., 2018; Majgaard, 2015). Please note that some of the benefits stated are not specific to humanoid robots and can be provided to some degree by computers, too.

A humanoid robot can:

- $\quad$ help strengthen the scientific and technological culture in schools;

- make abstract knowledge concrete in order to teach the real-world application of science, maths, programming and engineering;

- $\quad$ help students to increase their creativity, and build and strengthen their cognitive development;

- $\quad$ help students to become active problem solvers and engage them in their own learning;

- facilitate the transfer of knowledge through activity-based projects;

- $\quad$ be used to apply scientific thinking through enquiry-based activities;

- $\quad$ emphasise meaningful problem-based learning through the integration and application of knowledge;

- develop the ability of thinking through problems with a focus on logical reasoning, analytical reasoning and critical thinking;

- build the strategic problem-solving, computational thinking and higher-order thinking skills essential in science and engineering subjects.

Table 1

Roles of a humanoid robot in education

\begin{tabular}{ll}
\hline Role & Description \\
\hline Educational subject & $\begin{array}{l}\text { Humanoid robots can be used to help children learn basic algorithms by } \\
\text { programming objects and actions. }\end{array}$ \\
\hline Learning support tool & $\begin{array}{l}\text { Some educational activities can be successfully supported by humanoid } \\
\text { robots. Implementation of a humanoid robot-assisted teaching methodol- } \\
\text { ogy serves as a bridge between the acquisition and application of skills, } \\
\text { knowledge and attributes. }\end{array}$ \\
\hline Telepresence tool & $\begin{array}{l}\text { By acting as a telepresence tool, humanoid robots can enable sick or } \\
\text { hospitalised children to virtually attend classroom sessions at school. In } \\
\text { addition, this role enables the human teacher to connect to the classroom } \\
\text { and become virtually present through the humanoid robot's display. }\end{array}$ \\
\hline Assisting the education & $\begin{array}{l}\text { Humanoid robots can take a collaborative, complementary robot-human } \\
\text { approach to the daily tasks of a classroom setting, thus allowing the } \\
\text { teacher to focus on his/her pedagogical objective. }\end{array}$ \\
\hline
\end{tabular}

Note. Adapted from Abildgaard \& Scharfe, 2012; Kanda et al., 2004; Mubin et al., 2013; Pandey \& Gelin, 2019; Tazhigaliyeva et al., 2016. 
Humanoid robots can better serve the requirements of students with special needs. They can be programmed to suit each individual student's needs, thus offering special education in a much simpler and more accessible format; for instance, humanoid robots can help children with autism spectrum disorder (ASD) to learn communication and social skills, and can help children with attention disorders to learn how to focus (Huijnen et al., 2017; Scassellati et al., 2018).

Although the main benefits of humanoid robots in education are increased engagement and higher motivation, they should currently be understood as a learning tool rather than a teacher (Lee et al., 2008). One of the main drawbacks of the use of humanoid robots in teaching is that teachers are very hesitant about their integration in teaching-related activities. Interestingly, teachers are generally much more critical of humanoid robots in schools than students and parents are (ibid.). Therefore, teachers need to be reassured that the ultimate goal of integrating humanoid robots in teaching-related activities is not to replace them, but rather to equip them with a novel teaching tool that can enhance the learning experience and motivation of the students. Furthermore, most teachers are currently unaware of the technical capabilities of humanoid robots; they do not trust humanoid robots for teaching activities and are uncertain about how to use them efficiently. Most teachers therefore prefer to have full control in a classroom setting and only assign humanoid robots restricted roles.

\section{The roles and functions of humanoid robots in teaching a foreign language}

Teaching a foreign language is a difficult task. The goal is to inspire and motivate students for learning, reading, writing, speaking and comprehending the foreign language. Students face many difficulties while learning a foreign language, primarily due to the negative interference of their native language and cultural differences. It is known that students who learn a foreign language apply knowledge from their native language (Mora Pablo et al., 2011). Although this can make understanding and using the foreign language easier, it can also be an obstacle to the proper internalisation of the rules of the foreign language. Another barrier to foreign language learning is students' own culture. Cultural differences may cause cultural misunderstandings and confusion. Students may have difficulties in communicating and interacting with native speakers of the foreign language due to cultural differences, and are unable to obtain a level of proficiency if they cannot appropriately use the foreign language in the context 
of the culture of that language. Therefore, foreign language teachers must take into consideration the four strategies that students use to learn a foreign language (Hismanoglu, 2000). First, students tend to use their linguistic knowledge of their native language. Second, students attempt to transfer their cultural knowledge to make assumptions when communicating in the foreign language. Third, teachers must determine and highlight common features that may facilitate foreign language learning. Finally, teachers must be attentive to error correction, as errors may be the consequence of incorrect assumptions held about the culture of the foreign language or negative language transfer.

Although adults typically need to dedicate almost their whole time to learning a foreign language to achieve the desired goal (Deng \& Zou, 2016), children are capable of adapting to a particular situation much more easily, and learning a foreign language is often easier for them. Since children learn a foreign language faster, they should be provided with opportunities to attend foreign language courses. Nevertheless, most primary schools in developing countries such as Turkey do not currently offer foreign language courses (Çelik \& Kasapoğlu, 2014), although, due to the common interest in multilingualism resulting from globalisation, some of them are currently considering offering such courses (Ec.europa.eu, 2019). On the other hand, one of the biggest problems regarding this issue in developing countries is that if a primary school is not dedicated to students from immigrant families it typically employs only one or two foreign language teachers (native speakers), as it cannot generally absorb the expenses associated with more teachers. Furthermore, the teachers employed can only provide partial coverage due to timetable clashes. In this case, especially in big classes, a foreign language teaching assistant might be useful. This is the perfect role for a humanoid robot with multilingual interaction ability. Another important point in this regard is that children who have difficulties communicating with other children do not get appropriate public education. This situation is worse for children who cannot speak the official language of the country in which they live. If humanoid robots with multilingual interaction ability are equipped with appropriate interfacing mechanisms, they can be used to address this problem. However, if humanoid robots are going to be used in schools, they must be able to monitor everything that is happening in the classroom setting, to understand and interpret human language the way it is spoken, and to detect the emotions of each student. Another situation in which humanoid robots can be used is the teaching of sign language to hearing-impaired students (Al-Khulaidi et al., 2019).

According to the traditional foreign language teaching strategy, teachers play the role of the commander and students are the actors (Chang et al., 
2010). With this strategy, students can give commands during a learning activity, but some teachers may not be willing to follow the students' commands. In such cases, humanoid robots can be more successful than human teachers and maintain a higher level of engagement among the students (Xie, Antle, \& Motamedi, 2008). Despite being a traditional teaching strategy, task-based teaching is another foreign language teaching strategy in which humanoid robots can be used. According to this strategy, humanoid robots can play the role of manager/ stimulator, thus contributing to reducing the problem of classroom management and dealing with the problem of English avoidance (Kanda \& Ishiguro, 2005).

With the advancements in robotics in recent years, the use, benefits and challenges of humanoid robots have been thoroughly investigated. Alemi, Meghdari and Ghazisaedy (2014) examined the use of humanoid robots for high school students in vocabulary learning and retention of English, and studied the effects of this approach. The authors demonstrated that humanoid robots can be used to create an enjoyable and effective learning environment and reduce student anxiety regarding learning English. The authors also showed that the use of humanoid robots for foreign language teaching helps students to learn in a more effective manner and increases their motivation. However, there are very limited materials designed for Robot-Assisted Language Learning (RALL) sessions and RALL cannot be directly applied to adult learners. Initial experiments carried out over the last few years indicate that, although the use of humanoid robots for foreign language teaching provides better results compared to traditional human-based language teaching, human-robot cooperation is essential (Meghdari et al., 2013).

Due to the increasing interest in using humanoid robots for foreign language teaching, a great deal of research is being undertaken on this topic. For instance, Second Language Tutoring Using Social Robots (L2TOR) is a scientific research project funded by the Horizon 2020 programme. Its aim is to design a tutor robot that can be used to support teaching preschool children a foreign language by interacting with children in their social and referential world ("L2tor - Language robot."). It is assumed that a tutor robot designed using the hardware of a well-known humanoid robot called NAO (see Figure 1) will support teachers by spending time with children in one-to-one tutoring sessions ("L2tor - Language robot"). The tutor robot will incorporate languagebased tutoring about numbers and pre-mathematical concepts and spatial language, as well as facilitating basic vocabulary learning through storytelling. In addition to the role played by the tutor robot, a humanoid robot can also be used as a peer and learning tool; for instance, the NAO humanoid robot can be 
programmed to speak multiple languages, although its text-to-speech engines have limited prosodic capacities and generate synthetic voices (Belpaeme et al., 2018). Dominey and Dodane (2004) showed that children typically rely on prosodic cues to comprehend spoken language. In addition, humanoid robots do not have facial cues, which may hinder the auditory-visual perception processes of both normal-hearing and hearing-impaired children, making the role of humanoid robots in a classroom setting questionable (Erber, 1975).

Unlike humanoid robots, Androids/Geminoids are incredibly realistic, with their appearance closely resembling specific human models. Their bodies are constructed by precisely measuring human models with $3 \mathrm{D}$ scanners, and gypsum is typically used to capture facial contours accurately ("What is Geminoid?"; Ackerman, 2016). A perfect example of a Geminoid is Geminoid F, which was designed in 2010 and can make twelve different facial expressions using air pressure (Guizzo, 2010). It was modelled after a real woman and has life-like silicone skin, realistic black hair and pearly white teeth (Guizzo, 2010). Compared to ordinary humanoid robots, it is quite skilled. Its teleoperation feature uses a smart camera to track a real person's facial expressions, enabling it to reproduce facial tics and other unspoken gestures. It has recently been used to teach Japanese to a group of Vietnamese people ("Beautiful lifelike robot teaches Japanese in Vietnam"). Although a Geminoid might be a perfect foreign language teacher for adults, Robins, Dautenhahn and Dubowski (2006) have demonstrated that children, in their initial response, prefer interaction with a relatively simple, featureless robot rather than a realistic, human-like robot. Since the response of children towards the plain robot was more social and proactive, Geminoids may not be suitable for teaching a foreign language to children.

Most humanoid robots designed for foreign language teaching take the role of a teaching assistant (Yorita \& Kubota, 2012). Examples of such robots are IROBI (Han et al., 2008), the Telepresense robot (Kwon et al., 2010), Mero and Engkey (Lee et al., 2010), and the Humanoid robot (Chang et al., 2010). On the other hand, some humanoid robots, such as Robovie (Kanda et al., 2007), take the role of a learning companion or peer. Table 2 summarises the basic functions of a humanoid robot for various roles in foreign language teaching. Considering their typical skills, humanoid robots can be used in five different modes for foreign language teaching, as listed in Table 3. 


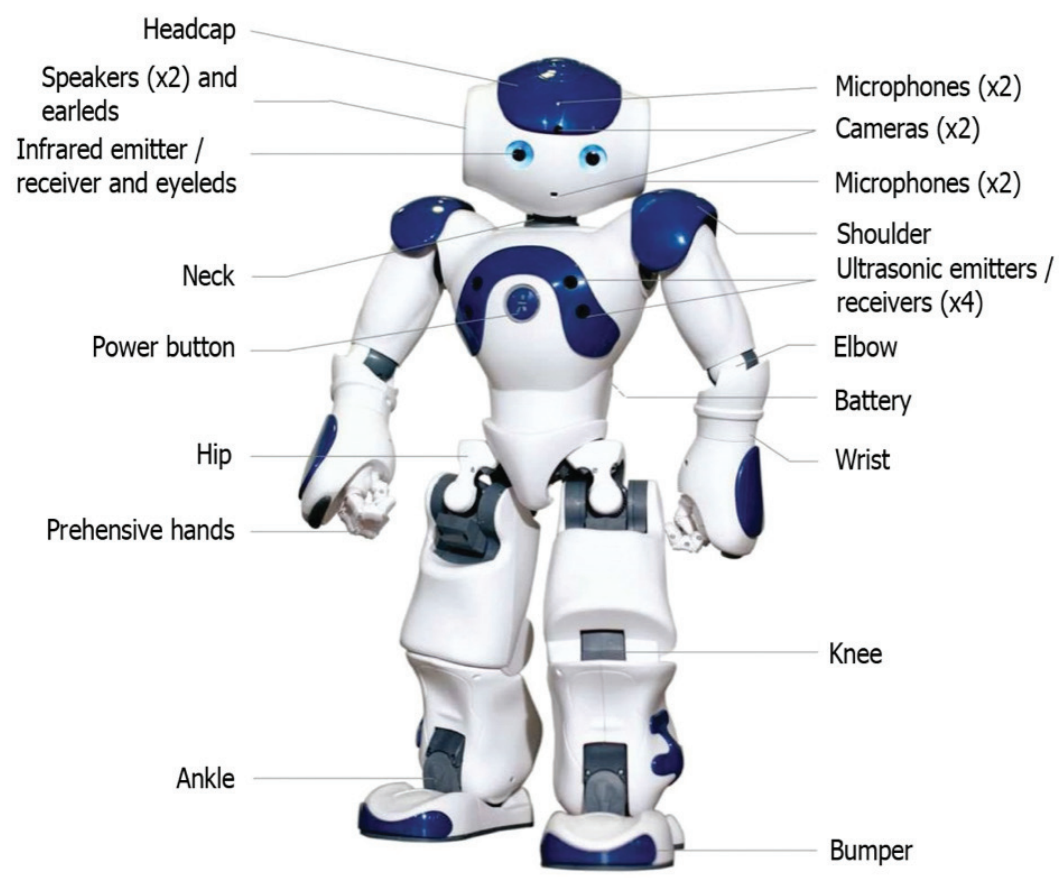

Figure 1. Humanoid robot NAO (Courtesy of SoftBank Robotics).

Table 2

Basic functions of a humanoid robot in teaching a foreign language

\begin{tabular}{ll}
\hline Role & Functions \\
\hline Tutor & $\begin{array}{l}\text { In this role, the humanoid robot acts as a tutor and performs various teaching- } \\
\text { related functions, such as helping students to memorise vocabulary (Saerbeck et } \\
\text { al., 2010). }\end{array}$ \\
\hline \multirow{2}{*}{ Peer } & $\begin{array}{l}\text { In this role, the humanoid robot acts as a peer (friend) and performs functions } \\
\text { related to learning goals such as acknowledging that the students pronounce } \\
\text { words correctly (Han \& Kim, 2009). }\end{array}$ \\
\hline Learning tool & $\begin{array}{l}\text { In this role, the humanoid robot itself acts as a learning tool; for instance, it can } \\
\text { play with the students to help them learn certain phrases (Mubin et al., 2013). }\end{array}$ \\
\hline
\end{tabular}

Note. Adapted from Chang et al., 2010. 
Table 3

Modes of a humanoid robot for foreign language teaching

\begin{tabular}{ll}
\hline Mode & Functions \\
\hline Oral reading & $\begin{array}{l}\text { In this role, the humanoid robot leads the students in repeating vocabu- } \\
\text { lary and sentences aloud. Using male/female voice transitions, it enables } \\
\text { the students to practise speaking in the roles of different characters. }\end{array}$ \\
\hline Storytelling & $\begin{array}{l}\text { In this role, the humanoid robot plays stories. While it is playing the } \\
\text { stories, it can also provide some sound effects or perform comic actions } \\
\text { to increase student engagement. }\end{array}$ \\
\hline \multirow{2}{*}{$\begin{array}{l}\text { In this role, the humanoid robot instructs the students to develop their } \\
\text { communicative competence so that they will be able to use the foreign } \\
\text { language properly to communicate and comment. }\end{array}$} \\
\hline $\begin{array}{l}\text { In this role, the humanoid robot asks the students to perform a number } \\
\text { of selected tasks. The students can also ask the humanoid robot to do } \\
\text { the same, and the robot obeys their instructions. This role is very useful in } \\
\text { encouraging students to improve their speaking skills. }\end{array}$ \\
$\begin{array}{l}\text { In this role, the humanoid robot helps the teacher to lead certain games in } \\
\text { which the students play individually or in groups. In addition, it can play } \\
\text { the role of a fair judge and a coach in competitive games. }\end{array}$ \\
\hline
\end{tabular}

Note. Adapted from Chang et al., 2010.

Due to the increasing interest in humanoid robots, their benefits in foreign language teaching were investigated in the Repeat Robot project carried out by Hemminki and Erkinheimo-Kyllönen (2017). The NAO humanoid robot shown in Figure 1 was used to assist in teaching Finnish as a second language. It was shown that humanoid robots can reduce the fear of making mistakes and thus promote speaking. Moreover, compared to a human teacher, it was easier for students to ask for help from the humanoid robot in the learning situation. The humanoid robot was able to support self-paced and self-guided learning. Finally, the humanoid robot was able to deal with the students' feelings. However, some obstacles were encountered during the interactions, mostly due to the speech recognition function of the humanoid robot, as speech recognition is typically challenging when the speaker is not native.

Due to their great interest in technological tools, the use of humanoid robots for foreign language teaching of students with ASD is highly promising. Alemi, Meghdari, Basiri and Taheri (2015) demonstrated that humanoid robot teachers can successfully teach a foreign language to students with highfunctioning ASD. On the other hand, it was shown that, if students with highfunctioning ASD are to be engaged in a language class, strategies such as a specific seating order and routine greetings can be used to increase the success of teaching (Wire, 2005). 
In summary, although the use of humanoid robots in foreign language teaching is promising and shows better learning outcomes (Alemi, Meghdari, \& Ghazisaedy, 2014; Kanda et al., 2004; Tanaka \& Matsuzoe, 2012), the impacts of robot embodiment in this context have not yet been investigated in detail (Belpaeme et al., 2018); for instance, an important question in this context is whether or not humanoid robots have advantages over virtual characters. Furthermore, the impacts of social behaviour have not yet been fully explored (Herberg et al., 2015), although some studies have presented positive results (Saerbeck et al., 2010) and it is clear that humanoid robots enable new possibilities and roles in teaching, such as the role of a peer. It has already been shown that the peer role reduces anxiety when learning a foreign language (Alemi, Meghdari, \& Ghazisaedy, 2015).

\section{Research challenges}

Teaching a foreign language requires teachers to learn to constantly adapt to their students' needs. Teachers must therefore be able to recognise and deal with a variety of problems in the classroom setting and find solutions to these problems. Not only do they have to be able to stay awake and interested in the class, they have to be able to keep their students awake and interested, as well. However, small tweaks in their teaching methods can help teachers to create a more productive and casual environment for both themselves and their students. Although humanoid robots can successfully address the second issue, the first one requires significant research in robotics so that sophisticated speech and recognition modules can be developed. Otherwise, it will not be possible for a humanoid robot to successfully manage the classroom setting alone.

Children are very interested in their social interaction, so humanoid robots must be able to create human-like interaction and communicate socially if they are going to be positioned in classrooms and function as an inspiring and engaging learning tool. For such interaction, humanoid robots must be able to recognise children's faces, detect basic emotions from children's facial expressions, adapt their behaviour to children's feelings, and finally display a broad range of common expressions and emotions themselves. These kinds of behaviours necessitate significant research efforts in robotics; for example, the voice of a humanoid robot is generally not natural, and even current sophisticated humanoid robots cannot adapt to situations by changing the tone or pitch of their voice. Owing to their limitations in speech and emotion recognition capabilities, humanoid robots are typically not situated in classrooms autonomously at the present time. 
Regarding teaching a foreign language to primary schools students, the most important issue to consider is that the students are already learning several subjects, so adding a foreign language may make effective learning difficult. Moreover, if the students' attention is further divided, other skills could be sacrificed. As the related literature shows, humanoid robots are successful at increasing student engagement, particularly at primary schools, thus creating a suitable environment for foreign language learning. However, another important issue is continuity, as only some high schools and universities offer foreign language courses, and the opportunity for necessary enhancement to the basic language skills obtained at a young age might not be available.

Humanoid robots designed for language teaching should collect data on their students' language skills and monitor the feelings and personal state of the students to identify things like confusion, boredom, sadness and joy. Human teachers make sense of all of the nonverbal cues they get from their students; therefore, if humanoid robots are going to be used as foreign language teachers they need to have a high level of social intelligence and state-of-the-art image processing skills that can analyse different facial muscle movements with a high degree of accuracy, so that they can dynamically adjust to how each student feels (Belpaeme et al., 2015; Belpaeme et al., 2018). Besides interpreting students' emotions, another important challenge is how to react to the information obtained from the student: What will the humanoid robot do if, for instance, the student gets bored?

One of the key shortcomings in the use of humanoid robots for foreign language teaching is the lack of well-defined curricula and learning material for teachers. Significant research efforts must therefore be devoted to the design of appropriate curricula and the development of learning material, as well as to the role of the teacher in addition to the development of robotic hardware and software (Mubin et al., 2013). Moreover, training teaching staff on humanoid robotics and how to execute curricula is essential. It is very clear that, if full integration of humanoid robots into our schools is desired and support from the teachers is expected, significant work must be done beforehand.

To sum up, the use of humanoid robots in education is fascinating and has huge potential, but it is also associated with enormous problems in terms of getting it right. Therefore, the lack of concrete evidence demonstrating the unique benefits of humanoid robots for foreign language teaching should be viewed as an opportunity to encourage interdisciplinary collaboration among experts (Kanero et al., 2018). Finally, although humanoid robots might be a promising solution for typical repetitive learning tasks of foreign language teaching, it is preferable to assign them a complementary learning tool role in the classroom setting, as they cannot hold students' attention by themselves. 


\section{Future research directions}

Since children can learn a foreign language faster than adults, they should take foreign language courses from a young age. In this way, they can attain a mastery of the foreign language as they grow older. As the literature shows, children from non-native-speaking countries of a foreign language can learn their own native language and the foreign language at the same time (Kaushanskaya, Yoo, \& Marian, 2011). The literature also shows that children become smarter if they are exposed to foreign languages at a young age.

The use of humanoid robots in education can help to close the gap between the best and worst schools, or between government-funded schools and private schools. For a number of reasons, including budget restrictions, government-funded schools find it hard to get the best teachers. However, the use of humanoid robots will address this issue, enabling the education received even in the most deprived region to be satisfactory. The prices of humanoid robots are currently high, but they may come down quickly if significant demand arises.

For a humanoid robot to act as a foreign language teacher for children, two of the major challenges are how to successfully interpret the students' emotions and how to react to that information. The humanoid robot should be designed and programmed in such a sophisticated way that it knows what to do when a child is frustrated or bored, or experiences some other emotion. In this way, the humanoid robot can be as friendly as possible to the child. On the other hand, the humanoid robot should also react to bad behaviour exhibited by the child. Significant time should be spent in observing teachers in kindergartens and primary schools so that humanoid robots can be programmed to successfully act like human foreign teachers.

It is known that, in most aspects, collaborative learning provides better outcomes than individual learning (Dillenbourg, 1999). In this regard, one of the questions that still needs to be addressed is whether the trend is the same while evaluating and comparing the learning processes of a student learning alone versus learning with a robot and versus learning with another student. This will show whether or not collaborative learning with a robot is as effective and time saving as learning with a human peer (Mubin et al., 2013).

In the last few years, various projects have been carried out to reveal how humanoid robot teachers can contribute to foreign language learning. The focus of these projects has mainly been to determine whether robots can successfully promote learning, as well as to examine the role of embodiment in robot teaching and the role of social interactions in teaching. Belpaeme et al. (2018) showed that, although humanoid robots are highly promising as teaching aids, 
we encounter a complex picture because children do not just learn by being exposed to a teaching robot. Therefore, employing humanoid robots in language learning requires thoughtful design decisions and practices in three respects: what the role of the humanoid robot is, how the child's learning is positively supported, and how the humanoid robot's interaction can support this.

Although the benefits of humanoid robots in teaching are clear, there are still several open issues regarding how humanoid robot teachers can be used effectively in an educational setting. Teaching a foreign language to young children necessitates a clear understanding of how foreign language learning occurs in young children and interpretation of how children can sufficiently benefit from teaching. Transferring teaching to humanoid robots rises many other questions (Belpaeme et al., 2018), such as: Should humanoid robots simulate what human teachers do? Should humanoid robots act as a teacher or a peer? How should humanoid robots blend the native language and the foreign language? How should feedback be given?

Appropriate feedback is commonly used to support foreign language learning (Ateş-Şen \& Küntay, 2015). Whereas positive feedback is explicitly provided, negative feedback is implicitly provided by recasting the correct information. Regarding the use of humanoid robots as a peer, evidence suggests that peers explicitly provide negative feedback without any correction, and that they do not generally provide positive feedback. The question therefore arises as to whether a humanoid robot should provide feedback when it takes the role of a peer (Belpaeme et al., 2018).

Last but not least, the possible effects of the use of humanoid robots on the human connection existing between teacher and students should not be neglected. The shift to humanoid robots in education may harm the connection if the possible effects are not investigated thoroughly. The teacher has something to gain or lose depending on the success or failure of the students, so s/he is motivated to push them academically. In this regard, humanoid robots designed to be used in schools must be able to show empathy in a convincing way, even if they are never be able to possess real emotional empathy.

\section{Conclusion}

The present paper has reviewed the functions of humanoid robots in foreign language teaching and examined novel approaches in the roles of humanoid robots. Research challenges and future research directions in this domain have also been presented. Although the literature does not provide support for the thesis that the physical presence of a humanoid robot alone has an 
advantage for foreign language learning, there is sufficient evidence that it has positive impacts on learning and various other interaction outcomes. Due to the scarcity of experimental data, the effect of a humanoid robot on foreign language learning is not yet clear; however, the social behaviour that the humanoid robot can manifest and its motivational benefits are totally clear.

As suggested in this paper, although humanoid robots with multilingual interaction skills can be used in foreign language teaching, their lack of emotional intelligence, intuition and spontaneity, all of which are naturally found in human teachers, makes it difficult for them to observe and understand students' reactions in order to ensure a smooth communication flow. Moreover, if humanoid robots are going to be used as an inspiring and engaging tool, they need to be capable of recognising faces, detecting basic emotions from facial expressions, displaying a broad range of expressions and emotions, and adapting their behaviour to their feelings. However, these skills require significant research in robotics. Therefore, instead of replacing a human teacher, humanoid robots are particularly useful for selected repetitive functions in foreign language teaching. Finally, humanoid robots might create the risk of chaos in the classroom setting, and setting up and turning on humanoid robots at the beginning of lessons is time consuming. Although humanoid robots are more effective than other digital devices, no study indicates that they are more effective than human teachers, so they will not make human teachers redundant. It is expected that, within a few years, the teacher will no longer be the person standing at the front of the classroom. Since some routine tasks, such as marking, assessment and lesson preparation, will be done using computer-based systems, the main role of human teachers will be as organisers and discipliners.

\section{Acknowledgement}

A preliminary and shorter version of this paper was presented at 5 th Teaching \& Education Conference, Amsterdam, June 19-22, 2018. This work was supported by the Research Fund of Trakya University. Project Number: $2017 / 132$.

\section{References}

Abildgaard, J. R., \& Scharfe, H. (2012). A Geminoid as lecturer. In S. S. Ge, O. Khatib, J. J. Cabibihan, R. Simmons, \& M. A. Williams (Eds.), Social Robotics. ICSR 2012. Lecture Notes in Computer Science (vol. 7621). Berlin \& Heidelberg: Springer.

Ackerman, E. (2016, February 08). Study: Nobody wants social robots that look like humans because 
they threaten our identity. Retrieved from https://spectrum.ieee.org/automaton/robotics/humanoids/ study-nobody-wants-social-robots-that-look-like-humans

Alemi, M., Meghdari, A., \& Ghazisaedy, M. (2014). Employing humanoid robots for teaching English language in Iranian junior high-schools. International Journal of Humanoid Robotics, 11(3), 1-25. Alemi, M., Meghdari, A., Basiri, N. M., \& Taheri, A. (2015). The effect of applying humanoid robots as teacher assistants to help Iranian autistic pupils learn English as a foreign language. Lecture Notes in Computer Science, 9388, 1-10.

Alemi, M., Meghdari, A., \& Ghazisaedy, M. (2015). The impact of social robotics on L2 learners' anxiety and attitude in English vocabulary acquisition. International Journal of Social Robotics, 7(4), 523-535.

Alimisis, D. (2012). Robotics in education \& education in robotics: Shifting focus from technology to pedagogy. In D. Obdrzálek (Ed.), Proceedings of the 3 rd International Conference on Robotics in Education (pp. 7-14). Retrieved from http://roboesl.eu/wp-content/uploads/2017/o8/Robotics-inEducation-Education-in-Robotics.pdf

Al-Khulaidi, R. A., Bakr, N. H. B. A., Fauzi, N. M., \& Akmeliawati, R. (2019). SignBot, sign-language performing robot, based on sequential motion of servo motor arrays. In J. H. Kim et al. (Eds.), Robot Intelligence Technology and Applications 5 (pp. 239-249). Retrieved from https://link.springer.com/ chapter/10.1007/978-3-319-78452-6_20 Ateş-Şen, A. B. \& Küntay, A. C. (2015). Children's sensitivity to caregiver cues and the role of adult feedback in the development of referential communication. In L. Serratrice \& S. E. M. Allen (Eds.), The Acquisition of Reference (pp. 241-262). Amsterdam: John Benjamins Publishing Company. Available languages - Aldebaran 2.1.4.13 documentation. (2019). Retrieved from http://doc. aldebaran.com/2-1/family/robots/languages.html Beautiful lifelike robot teaches Japanese in Vietnam. (2014, January 17). Retrieved from https:// tuoitrenews.vn/education/13039/modellike-robot-helps-teach-japanese-in-vietnam Belpaeme, T., Kennedy, J., Ramachandran, A., Scassellati, B., \& Tanaka, F. (2018). Social robots for education: A review. Science Robotics, 3(21), 1-9. doi:10.1126/scirobotics.aat5954 Belpaeme, T., Kennedy, J., Baxter, P., Vogt, P., Krahmer, E. J., Kopp, S., ... Deblieck, T. (2015). L2TOR - second language tutoring using social robots. In Proceedings of First International Workshop on Educational Robots.

Belpaeme, T., Vogt, P., Van den Berghe, R., Bergmann, K., Göksun, T., ... Pandey, A.

K. (2018). Guidelines for designing social robots as second language tutors. International Journal of Social Robotics, $10(3)$, 325-341.

Chang, C. W., Lee, J. H., Chao, P. Y., Wang, C. Y., \& Chen, G. D. (2010). Exploring the possibility of using humanoid robots as instructional tools for teaching a second language in primary school. Educational Technology \& Society, 13(2), 13-24.

Çelik, S., \& Kasapoğlu, H. (2014). Implementing the recent curricular changes to English language instruction in Turkey: Opinions and concerns of elementary school administrators. South African Journal of Education, 34(2), 842. 
Dautenhahn, K. (2007). Socially intelligent robots: dimensions of human-robot interaction. Philosophical transactions of the Royal Society of London. Series B, Biological sciences, 362(1480), 679-704.

Deng, F., \& Zou, Q. (2016). A study on whether the adults' second language acquisition is easy or not-from the perspective of children's native language acquisition. Theory and Practice in Language Studies, 6(4), 776-780.

Dillenbourg, P. (1999). What do you mean by “collaborative learning”? In P. Dillenbourg (Ed.),

Collaborative-learning: Cognitive and computational approaches (pp. 1-19). Oxford, UK: Elsevier.

Dominey P. F., \& Dodane, C. (2004). Indeterminacy in language acquisition: The role of child directed speech and joint attention. Journal of Neurolinguistics, 17(2-3), 121-145.

Ec.europa.eu. (2019). Retrieved from https://ec.europa.eu/eurostat/statistics-explained/ pdfscache/1151.pdf

Erber N. P. (1975). Auditory-visual perception of speech. The Journal of Speech and Hearing Disorders, $40(4), 481-492$.

Guizzo, E. (2010, April 4). Meet Geminoid F: A smiling female android. Retrieved from https:// spectrum.ieee.org/automaton/robotics/humanoids/o40310-geminoid-f-hiroshi-ishiguro-unveilsnew-smiling-female-android

Han, J., Jo, M., Jones, V., \& Jo, J. H. (2008). Comparative study on the educational use of home robots for children. Journal of Information Processing Systems, 4(4), 159-168.

Han, J., \& Kim, D. (2009). R-learning services for elementary school students with a teaching assistant robot. In V. Evers (Ed.), Proceedings 4 th ACM/IEEE International Conference on Human-

Robot Interaction (HRI) (pp. 255-256). doi: 10.1145/1514095.1514163

Hegarty, M. (2004). Dynamic visualizations and learning: getting to difficult questions. Learning and Instruction, 14(3), 343-351.

Hemminki, J., \& Erkinheimo-Kyllonen, A. (2017). A humanoid robot as a language tutor - a case study from Helsinki Skills Center. Paper presented at R4L@ HRI2017, Wien, Austria.

Herberg, J., Feller, S., Yengin, I., \& Saerbeck, M. (2015). Robot watchfulness hinders learning Performance. In Proceedings of 24th IEEE International Symposium on Robot and Human Interactive Communication (RO-MAN) (pp. 153-160). doi:10.1109/ROMAN.2015.7333620

Hismanoglu, M. (2000). Language learning strategies in foreign language learning and teaching. The Internet TESL Journal, 6(8). Retrieved from http://iteslj.org/Articles/Hismanoglu-Strategies.html Honig, S., \& Oron-Gilad, T. (2018). Understanding and resolving failures in human-robot interaction: Literature review and model development. Frontiers in Psychology, 9, 1-21. doi:10.3389/ fpsyg.2018.00861

Huijnen, C., Lexis, M., Jansens, R., \& de Witte, L. P. (2017). How to implement robots in interventions for children with autism? A co-creation study involving people with autism, parents and professionals. Journal of Autism and Developmental Disorders, 47(10), 3079-3096. Jamet, F., Masson, O., Jacquet, B., Stilgenbauer, J.-L., \& Baratgin, J. (2018). Learning by teaching with humanoid robot: a new powerful experimental tool to improve children's learning ability. Journal of 
Robotics, 2018, 1-11. doi: 10.1155/2018/4578762

Kanda, T., \& Ishiguro, H. (2005). Communication robots for elementary schools. In Proceedings of the Symposium on Robot Companions: Hard Problems and Open Challenges in Robot-Human Interaction (pp. 54-63).

Kanda, T., Hirano, T., Eaton, D., \& Ishiguro, H. (2004). Interactive robots as social partners and peer tutors for children: A Field Trial. Human-Computer Interaction, 19(1), 61-84.

Kanda, T., Sato, R., Saiwaki, N., \& Ishiguro, H. (2007). A two-month field trial in an elementary school for long-term human-robot interaction. IEEE Transactions on Robotics (Special Issue), 23(5), 962-971.

Kanero, J., Geçkin V., Oranç, C., Mamus, E., Küntay, A. C., \& Göksun, T. (2018). Social robots for early language learning. Child Development Perspectives, 12(3), 146-151.

Kaushanskaya, M., Yoo, J., \& Marian, V. (2011). The effect of second-language experience on nativelanguage processing. Vigo International Journal of Applied Linguistics, 8, 54-77. Retrieved from http:// vialjournal.webs.uvigo.es/pdf/Vial-2011-Article3.pdf

Kwok, V. H. Y. (2015). Robot vs. human teacher: Instruction in the digital age for ESL learners. English Language Teaching, 8(7), 157-163.

Kwon, O. H., Koo, S. Y., Kim, Y. G., \& Kwon, D. S. (2010). Telepresence robot system for English tutoring. In Proceedings of IEEE Workshop on Advanced Robotics and its Social Impacts (ARSO) (pp. 152-155).

Lee, E., Lee, Y., Kye, B., \& Ko, B. (2008). Elementary and middle school teachers, students and parents: perception of robot-aided education in Korea. In J. Luca \& E. R. Weippl (Eds.), Proceedings of World Conference on Educational Multimedia, Hypermedia and Telecommunications (pp. 175-183). Lee, S., Noh, H., Lee, J., Lee, K., \& Lee, G. G. (2010). Cognitive effects of robot-assisted language learning on oral skills. In T. Kobayashi, K. Hirose, \& S. Nakamura (Eds), Proceedings of the Interspeech 2010 Satellite Workshop on Second Language Studies: Acquisition, Learning, Education and Technology. Retrieved from http://www.gavo.t.u-tokyo.ac.jp/L2WS2010/papers/L2WS2010_P1-11.pdf Lopes, J., Engwall, O., \& Skantze, G. (2017). A first visit to the robot language café. In Proceedings of 7th ISCA Workshop on Speech and Language Technology in Education (pp. 7-12). doi: 10.21437/ SLaTE.2017-2L2tor - language robot. (n.d.). Retrieved from http://www.l2tor.eu/ Majgaard, G. (2015). Multimodal robots as educational tools in primary and lower secondary education. In Proceedings of International Conferences Interfaces and Human Computer Interaction 2015, Game and Entertainment Technologies 2015 and Computer Graphics, Visualization, Computer Vision and Image Processing 2015 (pp. 27-34).

Meghdari, A., Alemi, M., Ghazisaedy, M., Taheri, A. R., Karimian, A., \& Zandvakili, M. (2013). Applying robots as teaching assistant in EFL classes at Iranian middle-schools. In Proceedings of the International Conference on Education and Modern Educational Technologies (EMET 2013) (pp. 67-73).

Mora Pablo, I., Lengeling, M. M., Rubio Zenil, B., Crawford, T., \& Goodwin, D. (2011). Students and teachers' reasons for using the first language within the foreign language classroom (French and 
English) in Central Mexico. Profile Issues in Teachers ' Professional Development, 13(2), 113-129. Mubin, O., Stevens, C. J., Shahid, S., Al Mahmud, A., \& Dong, J. J. (2013). A review of the applicability of robots in education. Journal of Technology in Education and Learning, 1, 1-7. Retrieved from http:// roila.org/wp-content/uploads/2013/07/209-0015.pdf Pandey, A. K., \& Gelin R. (2019). Humanoid robots in education: A short review. In A. Goswami, P. Vadakkepat (Eds.), Humanoid robotics: A reference (pp. 1-16). Dordrecht: Springer.

Robins, B., Dautenhahn, K., \& Dubowski, J. (2006). Does appearance matter in the interaction of children with autism with a humanoid robot? Interaction Studies, 7(3), 479-512.

Saerbeck, M., Schut, T., Bartneck, C., \& Janse, M. (2010). Expressive robots in education - varying the degree of social supportive behavior of a robotic tutor. In Proceedings of the 28th ACM Conference on Human Factors in Computing Systems (CHI2010) (pp. 1613-1622).

Scassellati, B., Brawer, J., Tsui, K., Gilani, S. N., Malzkuhn, M., Manini, B., ... Petitto, L. A. (2018). Teaching language to deaf infants with a robot and a virtual human. In Proceedings of the $2018 \mathrm{CHI}$ Conference on Human Factors in Computing Systems. Retrieved from https://scazlab.yale.edu/sites/ default/files/files/pn4384-scassellatiA.pdf doi: 10.1145/3173574.3174127 Scassellati, B., Boccanfuso, L., Huang, C. M., Mademtzi, M., Qin, M., Salomons, N., ... Shic, F. (2018). Improving social skills in children with ASD using a long-term, in-home social robot. Science Robotics, 3(21), 1-9 doi: 10.1126/scirobotics.aat7544

Tanaka, F., \& Matsuzoe, S. (2012). Children teach a care-receiving robot to promote their learning: field experiments in a classroom for vocabulary learning. Journal of Human-Robot Interaction, 1(1), 78-95.

Tazhigaliyeva, N., Diyas, Y., Brakk, D., Aimambetov, Y., \& Sandygulova, A. (2016). Learning with or from the robot: Exploring robot roles in educational context with children. In A. Agah, J. J. Cabibihan, A. Howard, M. Salichs, \& H. He (Eds.), Social Robotics. ICSR 2016. Lecture Notes in Computer Science (vol. 9979). Springer.

What is geminoid? (n.d.). Retrieved from http://www.geminoid.jp/en/geminoid-development.html Wire, V. (2005). Autistic spectrum disorders and learning foreign languages. Support for Learning, $20(3), 123-128$.

Yorita A., \& Kubota, N. (2012). Mutual learning for second language education and language acquisition of robots. In U. Rückert, S. Joaquin, \& W. Felix (Eds.), Advances in Autonomous Mini Robots (pp. 75-87), Berlin \& Heidelberg: Springer.

Xie, L., Antle, A. N., \& Motamedi, N., (2008). Are tangibles more fun? Comparing children's enjoyment and engagement using physical, graphical and tangible user interfaces. In A. Schmidt, H. Gellersen, E. van den Hoven, A. Mazalek, P. Holleis, \& N. Villar (Eds.), Proceedings of the 2nd International Conference on Tangible and Embedded Interaction (pp. 191-198). 


\section{Biographical note}

Ayse Tuna, MS, is a lecturer in the field of foreign language teaching at the School of Foreign Languages at Trakya University, Turkey. Her research interests include support services for the elderly and disabled, education of autistic and handicapped children, human-robot interaction, and human-computer interaction.

Gurkan TunA, $\mathrm{PhD}$, is an associate professor in the field of computer science at the Vocational School of Technical Sciences at Trakya University, Turkey. His research interests include mobile robots, robotic sensor networks, wireless ad hoc and sensor networks, smart cities, and artificial intelligence. 